\title{
Old and stable soil organic matter is not necessarily chemically recalcitrant: Implications for modeling concepts and temperature sensitivity
}

Markus Kleber ${ }^{1}$, Peter S. Nico ${ }^{2}$, Alain Plante ${ }^{3}$, Timothy Filley ${ }^{4}$, Marc Kramer ${ }^{5}$, Christopher Swanston $^{6}$, Phillip Sollins ${ }^{7}$

${ }^{1}$ Department of Crop and Soil Science, Oregon State University, Corvallis, OR.

${ }^{2}$ Earth Sciences Division, Lawrence Berkeley National Laboratory, Berkeley, CA.

${ }^{3}$ Department of Earth and Environmental Science, University of Pennsylvania, Philadelphia, PA

${ }^{4}$ Purdue University, Department of Earth and Atmospheric Sciences, West Lafayette, IN.

${ }^{5}$ Earth \& Planetary Sciences Department, University of Santa Cruz, Santa Cruz, CA.

${ }^{6}$ Northern Research Station, USDA Forest Service, Houghton, MI.

${ }^{7}$ Department of Forestry, Oregon State University, Corvallis, OR.

* Corresponding author.

Phone 5417375718

Fax 5417375725

e-mail: markus.kleber@oregonstate.edu

Keywords: Soil organic matter, recalcitrance, density fractions, turnover time, radiocarbon, stable isotopes, differential scanning calorimetry (DSC), scanning transmission X-ray microscopy (STXM), near edge x-ray absorption fine structure spectroscopy (NEXAFS) 


\section{Abstract}

Soil carbon turnover models generally divide soil carbon into pools with varying intrinsic decomposition rates. While these decomposition rates are modified by factors such as temperature, texture, and moisture, they are rationalized by assuming chemical structure is a primary controller of decomposition. In the current work, we use Near Edge X-ray Absorption Fine Structure (NEXAFS) spectroscopy in combination with differential scanning calorimetry (DSC) and alkaline $\mathrm{CuO}$ oxidation to explore this assumption. Specifically, we examined material from the $2.3-2.6 \mathrm{~kg} \mathrm{~L}^{-1}$ density fraction of three soils of different type (Oxisol, Alfisol, Inceptisol). The density fraction with the youngest ${ }^{14} \mathrm{C}$ age (Oxisol, 107 years) showed the highest relative abundance of aromatic groups and the lowest O-alkyl $\mathrm{C} /$ aromatic $\mathrm{C}$ ratio as determined by NEXAFS. Conversely, the fraction with the oldest $\mathrm{C}$ (Inceptisol, 680 years) had the lowest relative abundance of aromatic groups and highest Oalkyl C/aromatic $\mathrm{C}$ ratio. This sample also had the highest proportion of thermally labile materials as measured by DSC, and the highest ratio of substituted fatty acids to lignin phenols as indicated by $\mathrm{CuO}$ oxidation. Therefore, the organic matter of the Inceptisol sample, with a ${ }^{14} \mathrm{C}$ age associated with 'passive' pools of carbon (680 years), had the largest proportion of easily metabolizable organic molecules with low thermodynamic stability, while the organic matter of the much younger Oxisol sample (107 years) had the highest proportion of supposedly stable organic structures considered more difficult to metabolize. Therefore, our results demonstrate that $\mathrm{C}$ age is not necessarily related to molecular structure or thermodynamic stability, and we suggest that soil carbon models would benefit from viewing turnover rate as co-determined by the interaction between substrates, microbial actors and abiotic driving variables. Furthermore, assuming that old carbon is composed of complex or "recalcitrant" compounds will erroneously attribute a greater temperature sensitivity to those materials than they may actually possess. 


\section{Introduction}

The predicted magnitude of the biospheric response to increasing heat content in the atmosphere varies greatly between different coupled climate and carbon cycle models (Friedlingstein et al., 2006), indicating a high degree of mechanistic uncertainty. Of the important feedbacks not yet considered in simulations of the carbon-cycle-climate system, below-ground processes are thought to be especially important (Heimann \& Reichstein, 2008). Among below-ground processes, the mechanisms that govern the decomposition of old (but non-charcol) soil carbon constitute a problem space that has seen significant conceptual debate and the publication of contradictory experimental results over the last few years.

Carbon pools with long turnover times are currently assumed to make up most of the organic carbon in soils (Davidson \& Janssens, 2006, von Lützow \& Kögel-Knabner, 2009). Several explanations have been proposed to explain the existence of old $\mathrm{C}$ including chemical recalcitrance, physical stabilization, and recycling. Because recalcitrance is used by different groups to mean different things, for this work we define chemical recalcitrance as an inherent chemical property of a molecule rendering it resistant to decomposition(Sollins et al., 1996). This property is usually associated with complex aromatic structures such as lignin or soil organic carbon that has been 'humified.' However, there is a growing body of publications which questions the importance of chemical recalcitrance as a stabilization mechanisms while emphasizing the importance of other stabilization mechanisms and the need to decouple chemical recalcitrance from the age of C (Hedges \& Oades, 1997, Mayer \& Xing, 2001, Czimczik \& Masiello, 2007, Torn et al., 2009, Trumbore, 2009). In addition, Paul et al. (2006) state that the high correlations between different methodologies based on tracers and analytical methods that give different mean residence times for physical and chemical soil 
fractions can best be explained by the hypothesis that young SOC does not differ greatly in composition from older SOC. They further suggested that SOC may not necessarily change with age once it is formed (Paul et al., 2006) and that operational fractions resistant to acid hydrolysis do not necessarily infer chemical recalcitrance. Other authors find no evidence that humification processes are indeed creating recalcitrant humic substances (Burdon, 2001, Kelleher \& Simpson, 2006, Lehmann et al., 2008). There are several reports that organic matter coatings on aluminosilicate surfaces consisted of labile, microbially processed materials (Rasmussen et al., 2005, Buurman et al., 2007, Grasset et al., 2009) but exhibited a relatively old radiocarbon age (Rasmussen et al., 2005, Sollins et al., 2006). Alkyl C in clay size fractions has been proposed to be "recalcitrant" (Baldock \& Skjemstad, 2000), but direct, stable isotope based investigations into the turnover dynamics of lipid biomarkers showed that they typically turn over faster than bulk C (Wiesenberg et al., 2004, Kramer \& Gleixner, 2006, Amelung et al., 2008, Bol et al., 2009)

While conceptual models of $\mathrm{C}$ stabilization continue to become more refined, major computational soil carbon turnover models such as Century and RothC simply divide soil carbon into pools with varying intrinsic decomposition rates. While movement between pools and the pool associated decomposition rates are modified by temperature, texture, and moisture, the base rates associated with the most stable $\mathrm{C}$ pools are conceptually justified as the composite impact of physical protection and chemical recalcitrance. Conversely, both models assign microbial biomass and associated metabolites to a $\mathrm{C}$ pool (Metherell et al., 1993, Jenkinson et al., 2008) with a fast turnover rate constant. While this approach has enjoyed significant success, the extent to which these conceptual assumptions are correct becomes important when considering the response of soil organic matter decomposition to changes in temperature because different stabilization mechanisms are likely to show different temperature sensitivities. While the models described above are intended to model 
soil $\mathrm{C}$ in it's entirely, for the current work we focused specifically on mineral associated organic matter.

When organic matter is partially removed from soil materials by chemical or physical methods, the residual mineral-associated organic materials are typically much older compared to the carbon in the bulk soil (Wattel-Koekkoek et al., 2003, Kleber et al., 2005). Organic matter in intimate contact with mineral surfaces is often depleted in recalcitrant aromatic structures like lignin and phenolic components (Guggenberger et al., 1994, Kiem \& Koegel-Knabner, 2003), and enriched in carboxyl and O-alkyl carbon, which are considered highly labile structures (Mahieu et al., 1999, Spielvogel et al., 2008). However, information about the molecular composition of old organic matter (other than charcoal) is difficult to obtain, since old organic matter is typically closely associated with mineral surfaces (Flessa et al., 2008). The goal of the current work was to provide detailed molecular structure information on old mineral associated $\mathrm{C}$ using near edge $\mathrm{X}$-ray absorption fine structure (NEXAFS) spectroscopy, differential scanning calorimetry (DSC), and cupric oxide (CuO) oxidation. The strength of the NEXAFS technique is that it allows us to examine the molecular features of organic carbon without the analytical constraints (e.g. paramagnetic iron in NMR spectroscopy, thermal artifacts in pyrolysis) that sometimes complicate classical methods of organic matter analyses.

\section{Materials and Methods}

We specifically examined organo-mineral associations isolated from three different soil types (Oxisol, Alfisol, Inceptisol) with previously measured carbon turnover times of 107, 175, and 680 years, respectively (Sollins et al., 2009). We chose the $2.3-2.6 \mathrm{~kg} \mathrm{~L}^{-1}$ density fraction because particulate organic matter has been removed at this density and the remaining organic matter is closely associated with minerals. Our choice of sample was 
additionally motivated by the observation of greater enrichment in ${ }^{13} \mathrm{C}$ and ${ }^{15} \mathrm{~N}$ with increasing turnover time (Figure 1A), implying an increasing fraction of microbial material (Dijkstra et al., 2006). Since microbial materials are comprised of significant proportions of proteins and polysaccharides, which are considered chemically labile, this trend provided a puzzling first indication for a growing proportion of labile materials with increasing turnover time. To provide a proximate measure of the thermal lability of the organic materials we employed differential scanning calorimetry (DSC). Alkaline $\mathrm{CuO}$ oxidation was used to determine the relative contributions of lignin phenolics and substituted fatty acids as indicators for the extent of organic matter transformations, and scanning transmission X-ray microscopy coupled with NEXAFS spectroscopy was used to achieve speciation of organic functional groups in individual clay-size organo-mineral microaggregates.

\section{Isolation of organo-mineral associations}

Samples were obtained by the sequential density fractionation of three soils as reported previously (Sollins et al., 2009). Soils were separated into fractions of increasing density by centrifugation of soil suspended in sodium polytungstate (SPT), aspiration of the floating material and supernatant, and vacuum filtration. Basic soil density fraction characteristics are given in Table 1. The Inceptisol sample was collected at the H.J. Andrews Experimental Forest in the Cascade Mountains, Oregon. The Oxisol samples were from a Rosario series Inceptic Hapludox from Susua State Forest, Puerto Rico. The Alfisol samples were from a Typic Hapludalf from Michigan State University's Kellogg Biological Station. Basic soil and sample characteristics, including stable isotope and radiocarbon data and details on turnover time calculations are provided in (Sollins et al., 2009). 


\section{Synchrotron near edge X-ray absorption fine structure (NEXAFS) spectroscopy}

NEXAFS data were obtained on the Molecular Environmental Sciences Beamline 11.0.2 at the Advanced Light Source (ALS), Lawrence Berkeley National Laboratory. Sample preparation and data collection were performed as reported by Wan et al. (2007). Material from the $2.3-2.6 \mathrm{~kg} \mathrm{~L}^{-1}$ density fraction of each soil type was deposited on individual $\mathrm{Si}_{3} \mathrm{~N}_{4}$ windows obtained from Silson Ltd., England. To locate individual particles or microaggregates on the window, survey scans were performed at $280 \mathrm{eV}$, below the $\mathrm{C}$ edge. Except as noted below, we disregarded particles with optical density greater than 2.0 at any energy between $278 \mathrm{eV}$ and $330 \mathrm{eV}$, i.e. the energy range of our carbon K-edge spectra. This limited particle selection to those smaller than one to two microns. In the Alfisol sample three particles had peak OD's of 2.13, 2.33, and 2.55 respectively. $\left[\mathrm{OD}=\log \left(\mathrm{I}_{\mathrm{o}} / \mathrm{I}\right)\right.$, where $\mathrm{I}_{\mathrm{o}}$ is the background photon flux transmitted through the $\mathrm{Si}_{3} \mathrm{~N}_{4}$ window measured within a clean area on the same $\mathrm{Si}_{3} \mathrm{~N}_{4}$ window, and $\mathrm{I}$ is the photon flux transmitted through a region within the sample]. However, the highest absorbing regions of these particles were not used when extracting the $\mathrm{C}$ spectra in order to avoid any spectral distortion due to high ODs. Spectra stacks were collected for the selected particles, which involves collected successive images of the particles for a series of ascending closely spaced energies. Spatially resolved spectra can then be extracted from these stacks. We collected stacks in the region of $278 \mathrm{eV}$ to $330 \mathrm{eV}$ broken into five different regions with different energy spacing between the images. Images were collected every $0.5 \mathrm{eV}$ between 278 and $282 \mathrm{eV}$; every $0.1 \mathrm{eV}$ between 282 and 290.1 $\mathrm{eV}$; every $0.5 \mathrm{eV}$ between 290.1 and $310 \mathrm{eV}$ and every $1 \mathrm{eV}$ between 310 to $330 \mathrm{eV}$. Maps of total $\mathrm{C}$ distributions were then obtained using a pixel size of $25 \mathrm{~nm}$, as differences of two absorption images recorded with monochromatic X-ray energies of 280 and $288.4 \mathrm{eV}$ for background and $\mathrm{C}$ absorption, respectively. The absorption images were converted to $\mathrm{OD}$ 
images before subtraction. These maps were obtained by subtracting below-edge OD maps from their corresponding above-edge OD map.

Carbon NEXAFS stack alignment and analyses, and alignment of background and edge maps of other elements were done using the Zimba alignment module of the software package aXis2000 (Hitchcock, 2006). Functional groups and resonance peak energies used to characterize organic carbon species were taken from the compilation given in Table 2.

A semiquantitative analysis of NEXAFS spectra was carried out by peak deconvolution using the software PeakFit ${ }^{\mathrm{TM}}$ v4 (SeaSolve Software Inc.). Peak positions were assigned according to Table 2. Following the conventions of Solomon et al. (2005) and Schumacher et al. (2005), the transitions of an electron from the $1 \mathrm{~s}$ orbital to an aromatic $\pi^{*}$ orbital at 285 $\mathrm{eV}$ will be referred to as aromatic $\mathrm{C}$. The $1 \mathrm{~s} \rightarrow \pi^{*}$ transition at $286.5 \mathrm{eV}$ will be designated phenolic C, the signals at $289.5 \mathrm{eV}$ will be called O-alkyl C and the resonance around $290 \mathrm{eV}$ as carbonyl-C. The region between 288.2 and $288.8 \mathrm{eV}$ includes transitions associated with amide $\mathrm{C}=\mathrm{O}$ and those of carboxyl carbon, but we decided to follow the convention of Schumacher et al. (2005) and designate it as carboxyl C. The $1 \mathrm{~s} \rightarrow 3 \mathrm{p} / \sigma^{*}$ transition near $287.5 \mathrm{eV}$ will be designated as aliphatic $\mathrm{C}$. The deconvolution procedure was applied to the extracted spectra through the energy region from 278 to $310 \mathrm{eV}$. In spectra with large, potentially interfering potassium resonances at 295 and $302 \mathrm{eV}$, these resonances were manually removed and replaced with a straight line. Although the resonances of interest are all well below these energies, this first order correction was employed as an extra safeguard against fitting distortion from these large resonances. No attempt was made to subtract the contribution of the K edge jump associated with these peaks, but given the fact that this edge should be much smaller than the resonance peaks, the likelihood of it causing noticeable 
fitting distortion was deemed acceptably low. Spectra were normalized to an edge jump of unity at $310 \mathrm{eV}$ to account for differences in the absolute amount of $\mathrm{C}$ on the particles. This energy is beyond the location of specific resonances and is accepted as a reasonable representation of the total elemental $\mathrm{C}$ content. This approximation is further experimentally justified by the observation that the spectra are featureless beyond this energy (data not shown). Gaussian peaks with the energies listed above were used to fit the specific bonding resonances. All of the $\pi$ resonance peaks were fitted using the same FWHM variable that was initially guessed as unity, but was allowed to vary during the fit. However, the final results never deviated more than $10 \%$ from this initial guess.

The ionization threshold was represented using a 'transition function' in the PeakFit curve library. This transition function emulates the arctangent function used by other researchers. The magnitude and FWHM of this function was fixed at unity to match the normalized data and the edge position was set at $290 \mathrm{eV}$ in agreement with previous studies. The $\sigma^{*}$ transitions were modeled using two additional gaussian functions with initial energy positions at 294 and $303 \mathrm{eV}$. No restrictions were placed on these peaks, and the final FWHM values and energy positions were generally in good agreement with the constraints imposed by Schumacher et al. (2005). Peak magnitude for all of the Gaussian transitions was allowed to vary freely, as was energy, although the peak positions naturally constrained themselves to the ranges given above.

\section{Thermal analyses}

Density fractions were subjected to thermal analyses as a rapid and integrative assessment of organic matter chemical and thermodynamic stability using a Netzsch STA 409PC Luxx simultaneous thermal analyzer equipped with a type-S TG-DSC sample carrier supporting a PtRh10-Pt thermocouple (Netzsch-Gerätebau GmbH, Selb, Germany). Samples were heated 
from 25 to $700{ }^{\circ} \mathrm{C}$ at a rate of $10{ }^{\circ} \mathrm{C} \min ^{-1}$ in an oxidizing atmosphere $\left(30 \mathrm{~mL} \mathrm{~min}{ }^{-1}\right.$ of synthetic air). Results were normalized to sample organic $\mathrm{C}$ content, and are reported in units of $\mathrm{mW}^{-1} \mathrm{C}$. Semi-quantitative analysis involved peak fitting of the resultant DSC thermograms (Plante et al., 2005). Peak fitting was performed using PeakFit. Baselines were corrected using non-parametric routines, and were calculated from the terminal region of the thermogram (generally at temperatures of $600-700{ }^{\circ} \mathrm{C}$ ). Peaks were fit using the residuals method with Gaussian peak types, allowing for negative peaks (endothermic) with variable peak widths. The initial number and placement of peaks were based on the shape of the thermograms, particularly the presence of signals that suggested separate thermal reactions. Fitting of the thermograms was performed iteratively until no change in the fitting statistics was observed. Deconvolution of the exothermic region of the three soils resulted in three or four individual Gaussian peaks (Table 3). The first peak centered near $100{ }^{\circ} \mathrm{C}$ records the endothermic reaction associated with hygroscopic water release. One peak centered at 297$314{ }^{\circ} \mathrm{C}$ (Peak A) and a second peak centered at $416-425{ }^{\circ} \mathrm{C}$ (Peak D) were common to all three soils. The small endothermic peak at $573{ }^{\circ} \mathrm{C}$ in the Alfisol signals the presence of quartz, while the source of the larger endothermic center at $478{ }^{\circ} \mathrm{C}$ in the Inceptisol sample is likely attributable to transformations of poorly crystalline minerals.

\section{Alterations in plant component composition}

Assessment of the contribution of plant components from the aromatic biopolymer lignin and the aliphatic biopolymers suberin and cutin was performed by alkaline $\mathrm{CuO}$ oxidation (Hedges \& Mann, 1979, Goni \& Hedges, 1990). Eight lignin phenols and nine hydroxyl and alkoxy-substituted fatty acids (SFA) were quantified as outlined in Filley et al. (2008). Compound yields are presented as $\mathrm{mg}$ compound per $100 \mathrm{mg}$ organic $\mathrm{C}(\Lambda 8$ designates the 
sum of the eight lignin phenols, and SFA is the sum of the nine substituted fatty acids). Estimation of lignin decay state is presented as the ratio of vanillic acid to vanillin (Acid/Aldehyde - Ac/Al ratio). Oxidative decay adds oxygen containing functional groups $(\mathrm{COOH})$, which are acidic. Thus the greater the Ac/Al ratio, the more advanced the state of lignin decomposition (Hedges et al., 1988).

\section{Results}

The exothermic regions (positive peaks) of the DSC data (Figure 1B) were used to provide a comparative assessment of the chemical and thermodynamic stability of the organic matter within the $2.3-2.6 \mathrm{~kg} \mathrm{~L}^{-1}$ density fraction of the three soils. The temperature scale position of an exothermal peak correlates with the activation energy for the thermal oxidation reaction (i.e. chemical stability), while peak intensity is a measure of the energy released during the reaction (i.e. a combination of energy content and compound abundance). Consequently, thermal reactions in the temperature region of Peak $\mathrm{A}\left(\approx 300^{\circ} \mathrm{C}\right)$ have been attributed to the decomposition of compounds such as carbohydrates and peptides, whereas those in the Peak $\mathrm{D}\left(\approx 420^{\circ} \mathrm{C}\right)$ range have been attributed to more aromatic components such as lignin (LopezCapel et al., 2005, Laird et al., 2008). The ratio between the areas of these two peaks (D/A) provides an index for the relative contribution of chemically labile compounds to more stable ones. Thermograms reported for classical humic acids and fulvic acids typically have high D/A ratios (Chen et al., 1978). Previously, decreases in this ratio have been taken to correspond with increases in biogeochemical lability (Leifeld, 2008). However, in our study

the decrease in this ratio (Table 3) was directly correlated with increases in $\Delta^{14} \mathrm{C}$ age of the samples (Figure1A). It is also directly correlated with greater microbial processing as determined by stable isotope analysis (Figure 1A). Since microbial compounds, proteins and 
polysaccharides, are also considered chemically labile compounds, all the evidence suggests that in these density fractions, the oldest organic matter is in fact the most chemically labile.

This result is further supported by the chemical differences observed in the CuO-extracted lignin phenols and suberin and cutin-derived substituted fatty acids (SFA) (Table 4).

The syringyl and vanillyl acid/aldehyde ratios $\left(\mathrm{Ac}_{\mathrm{Al}} \mathrm{Al}_{(\mathrm{s})}\right.$ and $\left.\mathrm{Ac} / \mathrm{Al}_{(\mathrm{v})}\right)$ of fresh plant organic matter are typically below 0.4 and this value increases with increasing microbial decay (Hedges et al., 1988). The Oxisol sample was characterized by the lowest $A c / \mathrm{Al}_{(\mathrm{s})} \mathrm{Ac} / \mathrm{Al}_{(\mathrm{v})}$ ratios, the greatest concentrations of lignin phenols, and the greatest concentration of substituted fatty acids (SFA), indicating it contained the most plant-like organic matter (Table 4). Furthermore, the $A c / \mathrm{Al}_{(\mathrm{s})}$ and $\mathrm{Ac} / \mathrm{Al}_{(\mathrm{v})}$ ratios were directly correlated with turnover time, i.e. highest Ac/Al ratio from the sample with the longest turnover time. The relative proportion of extracted plant derived SFA to lignin phenols was greatest for the organic matter in the Inceptisol fraction, 680 years and similar for the Oxisol and Alfisol samples, 107 and 175 years respectively. Increasing $\mathrm{Ac} / \mathrm{Al}_{(\mathrm{s})}$ and $\mathrm{Ac} / \mathrm{Al}_{(\mathrm{v})}$ ratios and decreasing lignin recovery have been previously observed with increasing particle density, decreasing particle size, or within aggregate gradients (Guggenberger et al., 1994, Sollins et al., 2006). Therefore, similar to the stable isotope and DSC results, the lignin and SFA analyses show a trend of organic materials becoming more microbial like and less chemically recalcitrant with increasing age.

For further investigation of this trend we obtained NEXAFS C 1s spectra for a total of 23 individual carbon-mineral microaggregates from the Oxisol $(n=8)$, Alfisol $(n=9)$ and Inceptisol ( $\mathrm{n}=6)$ samples (Figures 2-4). 
The spectra from the Fe-rich Oxisol sample are quite similar (Figure 2), whereas we observed considerable variation among the Alfisol and Inceptisol spectra (Figures 3 and 4). Close comparison of recurring spectral features showed that the spectra from all three samples could be grouped into three spectral types (Figure 5).

The Type 1 spectra had a strong signal near $285 \mathrm{eV}$, but showed little differentiation at higher energies, merely exhibiting a steady rise towards the carbon post-edge near 290-292 $\mathrm{eV}$. This spectral type was most common in the Oxisol sample accounting for $75 \%$ of the spectra. This undifferentiated type of spectrum has been reported for kerogen-type materials (Cody et al., 1998), but has not been commonly observed in soils or marine environments. It was the most abundant spectral type ( $\mathrm{n}=10$ or $43 \%$ of all particles/microaggregates), occurring in all three soils. Interestingly, this spectrum type was the most abundant in the subtropical Oxisol (Oxisol, $n=6$ out of 8 ), which had the fastest turnover time of the three samples.

The Type 2 spectra were characterized by three discernible peaks at $285 \mathrm{eV}$ (aromatic C), $286.5 \mathrm{eV}$ (phenolic C) and $288.5 \mathrm{eV}$ (amide and carboxyl C). This spectral type is seen in both the Alfisol sample and the Inceptisol. Spectra of this type have been frequently reported for alkaline extracts of organic matter (Lehmann et al., 2005), melanoidin produced by the reaction of lysine with glucose (Brandes et al., 2004), organic matter in microaggregates (Kinyangi et al., 2006), water dispersible colloids (Schumacher et al., 2005) and aquatic dissolved organic matter (Schumacher et al., 2006). While the Type 2 spectrum resembles the spectra most often reported in NEXAFS investigations of soils and non-marine aquatic systems, it represented only $n=7$ or $30 \%$ of all particles in our study.

The Type 3 spectra showed a resonance at the $285 \mathrm{eV}$ aromatic $\mathrm{C}$ region followed by a steep rise to a peak at $288.5 \mathrm{eV}$ (carboxyl C) followed by a roughly constant signal intensity. 
This spectral type was also seen in both the Alfisol and Inceptisol samples. The Type 3 pattern is most similar to spectra taken of microbial tissues, strongly implying that this spectral type represents $\mathrm{OM}$ composed of microbial material or material that has been processed by microbial metabolism. Spectra of this kind have been reported for marine particles rich in proteins and aliphatics (Brandes et al., 2004). Lehmann et al. (2007, Figure 6) reported similar spectra for organic matter associated with mineral surfaces within microaggregates. Similarly, Schumacher et al. (2005, Figure 1) used cluster analysis to extract a spectrum from the interior region of an aggregate that shows the Type 3 pattern, whereas the spectrum from the particle exterior was of Type 2 .

The results of the semi-quantitative fitting of the NEXAFS spectra both as a function of spectral type and soil type are shown in Table 5. Several important trends can be seen in these data. First, the relative proportion of aromatic $\mathrm{C}$ declined from Type 1 to Type 2 to Type 3 , while the proportion of amide and carboxyl groups $(288.5 \mathrm{eV})$ increased in the same order (Table 5A).

Described another way, the relative aromaticity $[(\operatorname{aromatic} \mathrm{C}) /($ amide and carboxyl $\mathrm{C})]$, Table 5A) decreased from Type 1 to Type 3, while the ratio of $\mathrm{O}$-alkyl $\mathrm{C}$ to aromatics increased from Type 1 to Type 3. These differences can be explained by assuming that Type 1 spectra represent organic materials in an early decomposition stage, while Type 2 and Type 3 spectra are indicative of progressively more advanced stages of decomposition. Re-sorting the data in Table 5A by soil type (Table 5B) reveals that the derived aromaticity and O-alkyl $\mathrm{C} /$ aromatic $\mathrm{C}$ ratios vary in a manner similar to the changes seen in the three spectral types. Specifically, the density fraction with the fastest turnover (Oxisol, 107 years) shows the highest relative aromaticity and the lowest $\mathrm{O}$-alkyl $\mathrm{C} /$ aromatic $\mathrm{C}$ ratio, while the density fraction with the slowest turnover (Inceptisol, 680 years) shows the lowest relatively 
aromaticity and highest $\mathrm{O}$-alkyl C/aromatic $\mathrm{C}$ ratio (Table $5 \mathrm{~A}, \mathrm{~B}$ ). The changes in the soil spectral characteristics can be understood similarly to that of the spectral types by postulating that the extent of organic matter decomposition changes consistently with increasing turnover time (Figure 1C) from Oxisol (107 yr) over Alfisol (175 yr) to Inceptisol (680 yr) and that the fraction of microbially derived material is greatest in the fraction with the oldest $\mathrm{C}$ (Inceptisol).

\section{Discussion}

Carbon turnover models have historically treated the carbon that turns over on very long time scales as the refractory carbon pool (Falloon \& Smith, 2000). Organic functional groups such as aromatic rings are thought to contribute to the recalcitrance of macromolecular syntheses products due to thermodynamic barriers to their decomposition, whereas compounds like carbohydrates are considered labile because of the relatively low activation energies required for their oxidation (Davidson \& Janssens, 2006). We found no indication that materials with the characteristics attributed to highly humified products are a major constituent of organo-mineral associations with a mean turnover time of 680 years. In fact, the Type 2 spectra, most frequently reported for classical alkaline extracted humic substances, were the least common spectra observed in our organic mineral associations. Rather, our results suggest a special role for microbially derived materials in organic matter stabilization. This insight is supported by the fact that mineral-associated organic matter with the longest mean residence time (i.e., the Inceptisol, with the lowest $\Delta^{14} \mathrm{C}$ ) showed the strongest evidence of microbial alteration, as indicated by three independent analyses, i.e. stable isotope data, $\mathrm{Ac} / \mathrm{Al}$ ratios, and $\mathrm{C}-\mathrm{NEXAFS}$ spectral character.

But the absence of recalcitrant, highly aromatic humic like organic compounds from mineral associated soil organic matter pools as observed in this study and as corroborated by 
an increasing number of reports (Grandy \& Neff, 2008, Kögel-Knabner et al., 2008, Marschner et al., 2008) has an intriguing indirect consequence. If stable organic matter, which is commonly understood to make up most of the organic carbon in soils (von Lützow \& Kögel-Knabner, 2009) is of a chemically labile molecular form then there are additional mechanisms keeping it from decomposing. The temperature sensitivity of those mechanisms is unknown and may likely be different than that predicted for chemically recalcitrant compounds using an activation energy approach (Feng \& Simpson, 2008).

We posit that the frequently encountered notion of a link between the "stability" or "recalcitrance" of soil organic matter and its temperature sensitivity (Fang et al., 2006, Conant et al., 2008, von Lützow \& Kögel-Knabner, 2009) may result from the reliance on an outdated molecular model for stable organic matter, at least when applied to the organic matter bound in the type of organo-mineral complexes studied here. Briefly, the carbon quality-temperature (CQT) theory of the temperature sensitivity of organic matter decomposition links the temperature sensitivity of old organic carbon to an increase in molecular complexity (Bosatta \& Agren, 1999, Davidson \& Janssens, 2006). The classical Humic Polymer Model of soil organic matter (Brady \& Weil, 2008) depicts stable organic material as large, covalently bonded humic polymers with unique chemical structures that are different from those of the starting materials (Schulten \& Schnitzer, 1997, Swift, 1999). Fragments are joined into polymeric macromolecules by strong covalent bonds, thus creating the complexity that is required by the CQT theory. But if old soil organic matter fragments are not large, complex, polymeric humic macromolecules (Piccolo, 2001, Sutton \& Sposito, 2005), then they lose the special temperature sensitivity as expected by the CQT theory. Therefore, we suggest that some of the contradictory evidence (Wixon \& Balser, 2009) in the ongoing discussion about the temperature sensitivity of the decomposition of soil organic carbon may result from the automatic assumption that stable, old organic matter is primarily 
composed of materials that are "chemically recalcitrant". A promising strategy towards an improved, mechanistic representation of soil organic matter turnover would be to view the persistence of soil organic matter as co-determined by the interaction between substrates, microbial actors and abiotic driving variables. In such an approach, instead of being defined by the ill-defined 'recalcitrance' of particular organic structures, organic matter turnover would be seen as dependent on the microbial ecology and resource availability of a given soil environment.

Table 1: Basic soil analysis. Data are an excerpt from Sollins et al. (2009). CEC is cation exchange capacity, subscript ' $\mathrm{o}$ ' indicates oxalate extraction, subscript ' $\mathrm{d}$ ' indicates dithionite extraction, BET $\mathrm{N}_{2}$ surface area is the surface area accessible to $\mathrm{N}_{2}$ gas and C-loading is the mass of organic carbon per surface area unit. OXI = oxisol; ALF $=$ Alfisol, $\mathrm{INC}=$ inceptisol.

\begin{tabular}{|c|c|c|c|c|c|c|c|}
\hline \multirow[b]{2}{*}{ Property } & \multirow[b]{2}{*}{ Unit } & \multicolumn{3}{|c|}{$\begin{array}{l}\text { Bulk soil } \\
<2 \mathrm{~mm}\end{array}$} & \multicolumn{3}{|c|}{$\begin{array}{l}\text { Density fractions } \\
2.3-2.6 \mathrm{~kg} \mathrm{~L}^{-1}\end{array}$} \\
\hline & & OXI & ALF & INC & OXI & ALF & $\mathrm{INC}$ \\
\hline Sand & $\mathrm{g} \mathrm{kg}^{-1}$ & 18.4 & 44.2 & 31.7 & & & \\
\hline Clay & $\mathrm{g} \mathrm{kg}^{-1}$ & 44.3 & 13.8 & 33.8 & & & \\
\hline $\mathrm{CEC}\left(\mathrm{NH}_{4} \mathrm{Ac}\right)$ & $\mathrm{cmol} \mathrm{kg}^{-1}$ & 39.9 & 8.1 & 20.8 & & & \\
\hline $\mathrm{pH}\left(\mathrm{CaCL}_{2}\right)$ & & 5.8 & 5.2 & 4.4 & & & \\
\hline $\mathrm{C}$ & $\mathrm{g} \mathrm{kg}^{-1}$ & 58 & 15 & 38 & 97 & 14 & 7.4 \\
\hline$\%$ of total soil C & & & & & 13.2 & 19.4 & 2.6 \\
\hline $\mathrm{N}$ & $\mathrm{g} \mathrm{kg}^{-1}$ & 4.3 & 1.1 & 1.8 & 7.3 & 1.5 & 0.6 \\
\hline $\mathrm{C}: \mathrm{N}$ & & 13.5 & 14.2 & 20.8 & 13.3 & 9.3 & 12 \\
\hline$\Delta^{14} \mathrm{C}$ & & 91.9 & 62.4 & 28.8 & 83.2 & 44.0 & -58.3 \\
\hline $\mathrm{MRT}^{\mathrm{b}}$ & years & & & & 107 & 176 & 684 \\
\hline$\delta^{13} \mathrm{C}$ & & & -26.5 & $-25.9^{\mathrm{a}}$ & -26.5 & -25.3 & -24.7 \\
\hline$\delta^{15} \mathrm{~N}$ & & & 2.0 & $3.9^{\mathrm{a}}$ & 1.4 & 4.4 & 5.4 \\
\hline $\mathrm{Fe}_{\mathrm{o}}$ & $\mathrm{g} \mathrm{kg}^{-1}$ & 9.8 & 3.9 & 9.3 & 5.9 & 6.8 & 8.3 \\
\hline $\mathrm{Al}_{\mathrm{o}}$ & $\mathrm{g} \mathrm{kg}^{-1}$ & 3.5 & 2.3 & 10.3 & 2.8 & 3.6 & 6.6 \\
\hline $\mathrm{Al}_{\mathrm{o}}+0.5 \mathrm{Fe}_{\mathrm{o}}$ & $\mathrm{g} \mathrm{kg}^{-1}$ & 8.4 & 4.3 & 14.7 & 5.8 & 7.0 & 10.8 \\
\hline
\end{tabular}




$\begin{array}{llllllll}\mathrm{Fe}_{\mathrm{d}}-\mathrm{Fe}_{\mathrm{o}} & \mathrm{g} \mathrm{kg}^{-1} & 194.4 & 1.0 & 3.2 & & & \\ \mathrm{Fe}_{\mathrm{o} / \mathrm{d}} & & 0.05 & 0.80 & 0.74 & & & \\ \text { BET N } & & & & & & & \\ \text { C-loading } & \mathrm{mg} \mathrm{m}^{-2} & 0.91 & 3.1 & 0.84 & 0.82 & 0.80 & 0.23\end{array}$

${ }^{\mathrm{a}}=$ determined after resampling

$\mathrm{b}=$ Mean Residence Time

Table 2: Assignment of functional groups and corresponding electron transitions to NEXAFS signals (Cody et al., 1998, Urquhart \& Ade, 2002, Schumacher et al., 2005, Wan et al., 2007)

\begin{tabular}{|c|c|c|}
\hline Functional groups & Transition & Energy range $(\mathrm{eV})$ \\
\hline Quinonic $\mathrm{C}=\mathrm{O}$ & $1 \mathrm{~s} \rightarrow \pi^{*}$ & $283.7-284.3$ \\
\hline $\begin{array}{l}\text { Aromatic } \mathrm{C} \text { bonded to } \\
\text { aromatic } \mathrm{C} \text {; aromatic } \mathrm{C}-\mathrm{H}\end{array}$ & $1 \mathrm{~s} \rightarrow \pi^{*}$ & $284-285.5$ \\
\hline $\begin{array}{l}\text { Phenolic } \mathrm{C}-\mathrm{OH} \text {; } \\
\text { ketonic } \mathrm{C}=\mathrm{O}\end{array}$ & $1 \mathrm{~s} \rightarrow \pi^{*}$ & $286.5-287.2$ \\
\hline Aliphatic C-H & $1 \mathrm{~s} \rightarrow 3 \mathrm{p} / \sigma^{*}$ & $287.1-287.8$ \\
\hline $\begin{array}{l}\text { Amide carbonyl (peptide) } \\
\mathrm{C}=\mathrm{O} \text {, carboxylic } \mathrm{C}=\mathrm{O} \text { and } \\
\mathrm{C}-\mathrm{OH}\end{array}$ & $1 \mathrm{~s} \rightarrow \pi^{*}$ & $288.0-288.8$ \\
\hline $\mathrm{C}-\mathrm{O}$ in O-alkyl C & $1 \mathrm{~s} \rightarrow \pi^{*}$ & 289.5 \\
\hline $\begin{array}{l}\text { Carboxyl substituted } \\
\text { aromatics, carbonyl } \mathrm{C}=\mathrm{O}\end{array}$ & $1 \mathrm{~s} \rightarrow \pi^{*}$ & $290.0-290.5$ \\
\hline
\end{tabular}


Table 3: Results from peak fitting of the exothermic region of differential scanning calorimetry (DSC) thermograms of density fractions $\left(2.3-2.6 \mathrm{~kg} \mathrm{~L}^{-1}\right)$ isolated from three soils.

\begin{tabular}{|c|c|c|c|c|c|c|c|c|c|c|c|}
\hline \multirow[b]{2}{*}{ Soil } & \multicolumn{2}{|l|}{ Peak A } & \multicolumn{2}{|l|}{ Peak B } & \multicolumn{2}{|l|}{ Peak C } & \multicolumn{2}{|l|}{ Peak D } & \multicolumn{2}{|l|}{ Peak E } & \multirow{2}{*}{$\begin{array}{l}\% \mathrm{D} / \% \mathrm{~A} \\
\text { peak } \\
\text { areas }\end{array}$} \\
\hline & $\begin{array}{l}\text { Temp, } \\
{ }^{\circ} \mathrm{C}\end{array}$ & Area & $\begin{array}{l}\text { Temp, } \\
{ }^{\circ} \mathrm{C}\end{array}$ & Area & $\begin{array}{l}\text { Temp, } \\
{ }^{\circ} \mathrm{C}\end{array}$ & Area & $\begin{array}{l}\text { Temp, } \\
{ }^{\circ} \mathrm{C}\end{array}$ & Area & $\begin{array}{l}\text { Temp, } \\
{ }^{\circ} \mathrm{C}\end{array}$ & Area & \\
\hline Oxisol & 299 & 2008 & 328 & 339 & 364 & 653 & 421 & 2400 & - & - & 1.3 \\
\hline Alfisol & 314 & 2887 & - & - & - & - & 416 & 1129 & 511 & 270 & 0.4 \\
\hline Inceptisol & 297 & 3345 & - & - & 379 & 1518 & 425 & 520 & - & - & 0.2 \\
\hline
\end{tabular}


Table 4: Concentration ( $\mathrm{mg} 100 \mathrm{mg}^{-1} \mathrm{C}_{\text {org }}$ ) and molecular parameters of lignin phenols and substituted fatty acids for density fractions $\left(2.3-2.6 \mathrm{~kg} \mathrm{~L}^{-1}\right)$ from three soils.

\begin{tabular}{|c|c|c|c|}
\hline & Oxisol & Alfisol & Inceptisol \\
\hline $\begin{array}{l}\text { Lignin phenols } \\
(\Lambda 8)\end{array}$ & 2.00 & 0.75 & 0.96 \\
\hline $\mathrm{C} / \mathrm{V}$ & 0.37 & 0.48 & 0.25 \\
\hline $\mathrm{S} / \mathrm{V}$ & 0.63 & 0.89 & 0.05 \\
\hline $\mathrm{Ac} / \mathrm{Al}(\mathrm{V})$ & 0.49 & 0.91 & 1.45 \\
\hline $\mathrm{Ac} / \mathrm{Al}(\mathrm{S})$ & 0.40 & 0.91 & 2.27 \\
\hline $\begin{array}{l}\text { Substituted fatty } \\
\text { acids (SFA) }\end{array}$ & 2.16 & 0.74 & 1.75 \\
\hline $\begin{array}{l}\text { SFA/Lignin } \\
\text { phenols }\end{array}$ & 1.08 & 0.99 & 1.83 \\
\hline
\end{tabular}


Table 5: Relative proportions of organic functional groups identified by C 1s NEXAFS spectroscopy in $2.3-2.6 \mathrm{~kg} \mathrm{~L} \mathrm{~L}^{-1}$ density fractions, sorted for A) spectrum type as assigned in Figure 5 and B) soil type. Numbers are mean values with standard deviation in brackets.

\begin{tabular}{|c|c|c|c|c|c|c|c|c|}
\hline & Aromatic & Phenolic & Aliphatic & $\begin{array}{c}\text { Amide } \\
\text { and Carboxyl }\end{array}$ & O-alkyl & Carbonyl & Aromaticity $^{\mathrm{a}}$ & $\begin{array}{c}\mathrm{O} \text {-alkyl/ } \\
\text { aromatic C } \mathrm{C}^{\mathrm{b}}\end{array}$ \\
\hline Photon energy (eV) & $284-285.5$ & $286.5-287.2$ & $287.1-287.8$ & $288.0-288.8$ & $289.5 \mathrm{eV}$ & $290.0-290.5$ & & \\
\hline \multicolumn{9}{|c|}{$\begin{array}{l}\text { Spectral type } \\
\text { (\% composition) }\end{array}$} \\
\hline Type $1(\mathrm{n}=10)$ & $17(4)$ & $12(2)$ & $16(2)$ & $22(2)$ & $20(2)$ & $12(3)$ & 0.77 & 1.19 \\
\hline Type $2(n=6)$ & $14(3)$ & $18(1)$ & $15(2)$ & $24(3)$ & $20(1)$ & $9(1)$ & 0.58 & 1.41 \\
\hline Type $3(n=7)$ & $12(1)$ & $10(3)$ & $17(2)$ & $26(2)$ & $21(1)$ & $13(1)$ & 0.47 & 1.73 \\
\hline \multicolumn{9}{|c|}{$\begin{array}{c}\text { Soil type } \\
\text { (\% composition) }\end{array}$} \\
\hline Oxisol (n=8) & $17(4)$ & $14(3)$ & $16(1)$ & $22(2)$ & $20(2)$ & $11(3)$ & 0.76 & 1.16 \\
\hline Alfisol $(n=9)$ & $14(3)$ & $13(5)$ & $16(2)$ & $24(3)$ & $21(2)$ & $12(3)$ & 0.59 & 1.47 \\
\hline Inceptisol $(\mathrm{n}=6)$ & $13(1)$ & $13(3)$ & $16(2)$ & $25(2)$ & $21(1)$ & $12(3)$ & 0.52 & 1.60 \\
\hline
\end{tabular}

${ }^{\text {a Aromaticity }}=($ Aromatic $) /($ Amide and Carboxyl $)$

${ }^{\mathrm{b}} \mathrm{O}$-alkyl/aromatic $\mathrm{C}=(\mathrm{O}$-alkyl $) /($ Aromatic $)$ 


\section{Figure captions}

Figure 1A) With decreasing ${ }^{14} \mathrm{C}$ abundance (given as $\Delta{ }^{14} \mathrm{C}$ ) and increasing turnover time $\left({ }^{14} \mathrm{C}\right.$-based), organic matter becomes more enriched in ${ }^{13} \mathrm{C}$ and ${ }^{15} \mathrm{~N}$. The $\Delta-\delta$ notation indicates the absolute value of isotopic enrichment in ${ }^{13} \mathrm{C}$ and ${ }^{15} \mathrm{~N}$ in \%o that was observed between light fraction $\left(<1.6 \mathrm{~kg} \mathrm{~L}^{-1}\right)$ and the dense fraction investigated $\left(2.3-2.6 \mathrm{~kg} \mathrm{~L}^{-1}\right)$ and was calculated as the difference between the $\delta^{13} \mathrm{C}$ of the dense fraction and the $\delta^{13} \mathrm{C}$ of the light fraction. Original data as published in Sollins et al. (2009) Brackets are single pool turnover times in years.

Figure 1B) Differential scanning calorimetry thermograms of the Inceptisol, Alfisol and Oxisol dense fractions showing endothermic (negative) peaks near $100^{\circ} \mathrm{C}$ due to water release and two exothermic peaks (near 300 and $400^{\circ} \mathrm{C}$ ) due to thermal oxidation of organic matter.

Figure 1C) As turnover time increases, oxidation state of lignin (Syringyl Ac/Al ratio) increases in the order Oxisol $<$ Alfisol $<$ Inceptisol in agreement with a decrease in thermal stability (DSC $420^{\circ} / 300^{\circ} \mathrm{C}$ peak ratio) and a decrease in aromaticity $(285 / 288 \mathrm{eV}$ peak ratios) as determined by NEXAFS.

Figure 2: Carbon NEXAFS spectra for 8 nanoaggregates from the $2.3-2.6 \mathrm{~g} \mathrm{~cm}^{-3}$ density fraction of an Oxisol A horizon. Vertical dashed lines indicate resonances of (a) aromatic, (b) phenolic, (c) aliphatic, (d) amide and carboxyl C, (e) O-alkyl and (f) carbonyl functional groups. The peaks at 297 and $300 \mathrm{eV}$ result indicate the $\mathrm{L}_{3}$ and $\mathrm{L}_{2}$ edges of potassium. Spectra are sorted into three groups: Type 1 is represented by thin continuous line, type 2 by 
thick continuous line and type 3 by dotted line. Spectral identity is documented by internal labels.

Figure 3: Carbon NEXAFS spectra for 9 nanoaggregates from the $2.3-2.6 \mathrm{~g} \mathrm{~cm}^{-3}$ density fraction of an Alfisol A horizon. Vertical dashed lines indicate resonances of (a) aromatic, (b) phenolic, (c) aliphatic, (d) amide and carboxyl C, (e) O-alkyl and (f) carbonyl functional groups. The peaks at 297 and $300 \mathrm{eV}$ result indicate the $\mathrm{L}_{3}$ and $\mathrm{L}_{2}$ edges of potassium. Spectra are sorted into three groups: Type 1 is represented by thin continuous line, type 2 by thick continuous line, and type 3 by dotted line. Spectral identity is documented by internal labels.

Figure 4: Carbon NEXAFS spectra for 6 nanoaggregates from the 2.3-2.6 $\mathrm{g} \mathrm{cm}^{-3}$ density fraction of an Inceptisol A horizon. Vertical dashed lines indicate resonances of (a) aromatic, (b) phenolic, (c) aliphatic, (d) amide and carboxyl C, (e) O-alkyl and (f) carbonyl functional groups. The peaks at 297 and $300 \mathrm{eV}$ result indicate the $\mathrm{L}_{3}$ and $\mathrm{L}_{2}$ edges of potassium. Spectra are sorted into three groups: Type 1 is represented by thin continuous line, type 2 by thick continuous line and type 3 by dotted line. Spectral identity is documented by internal labels.

Figure 5: Allocation of normalized NEXAFS spectra to three typical signal patterns. For each of the three types of spectra identified we show an overlay of all normalized spectra considered to belong to this type, the average spectrum (obtained by averaging the $n$ values for each energy value, with $n=$ number of spectra) and the derived general spectral type. 

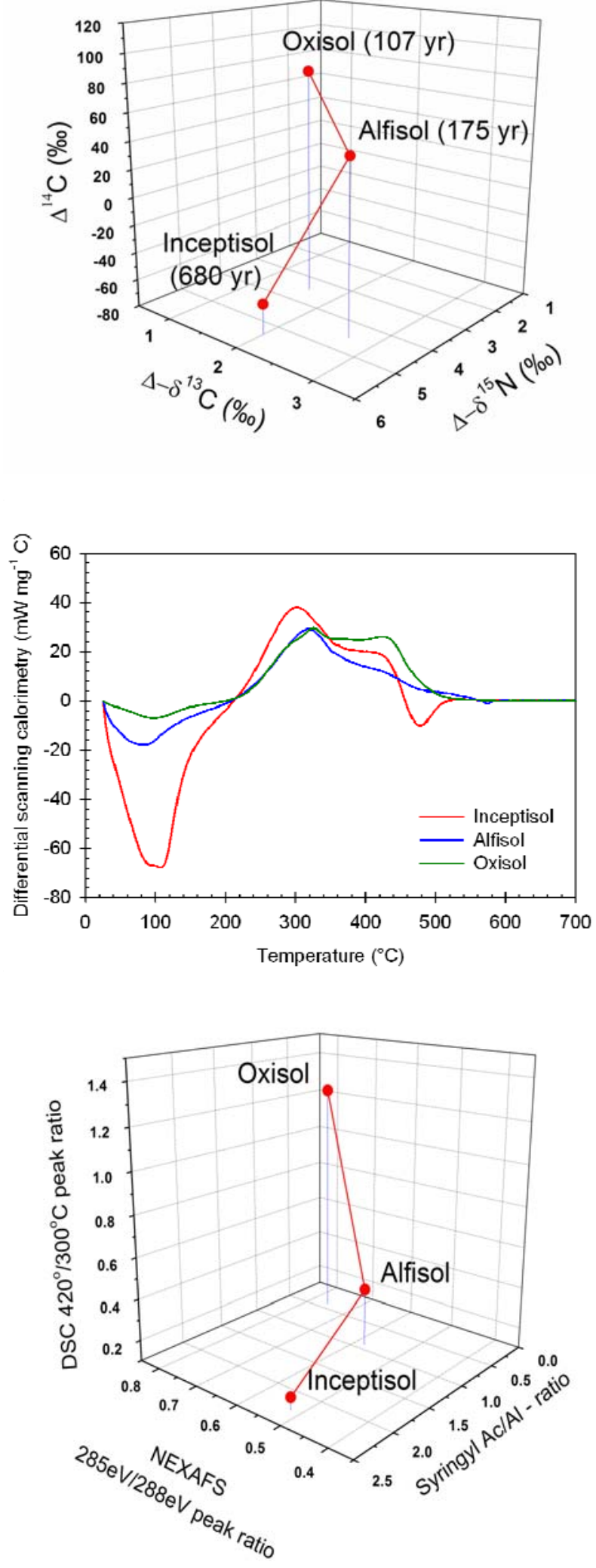

Figure 1 


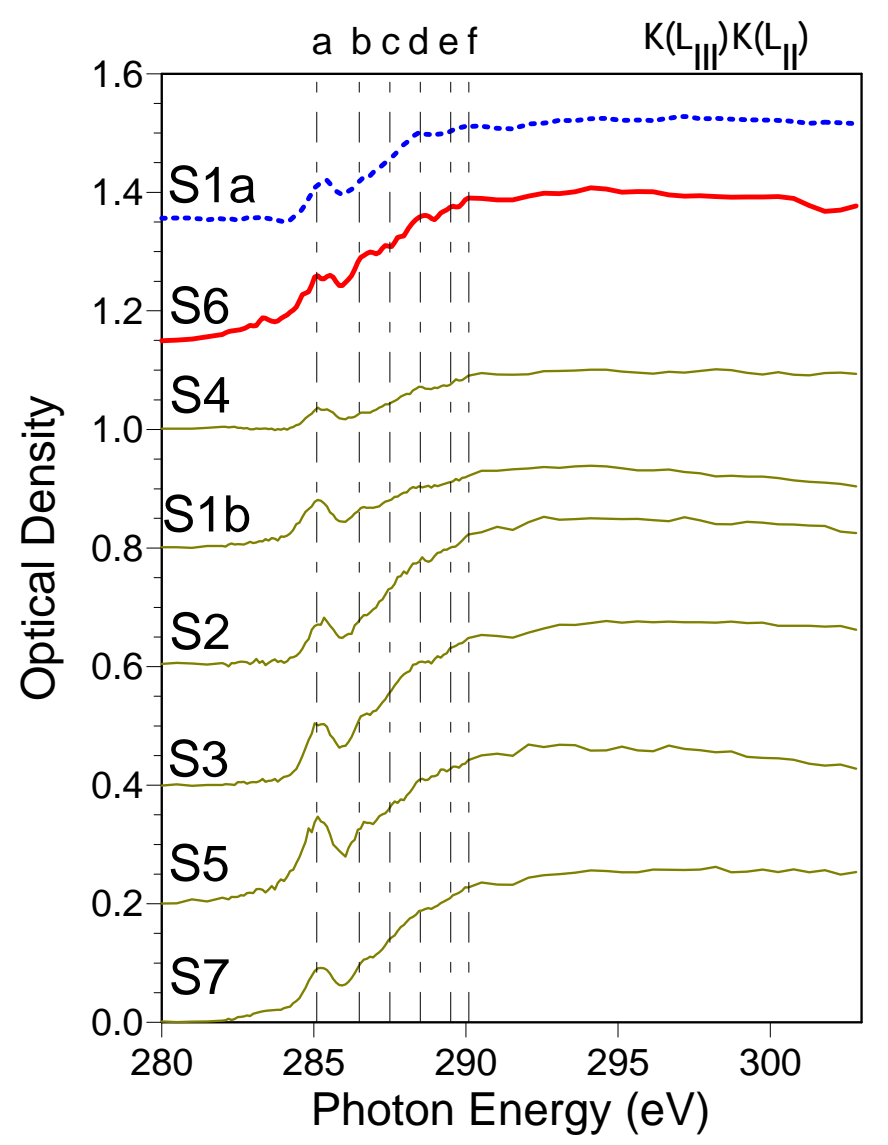

Figure 2 


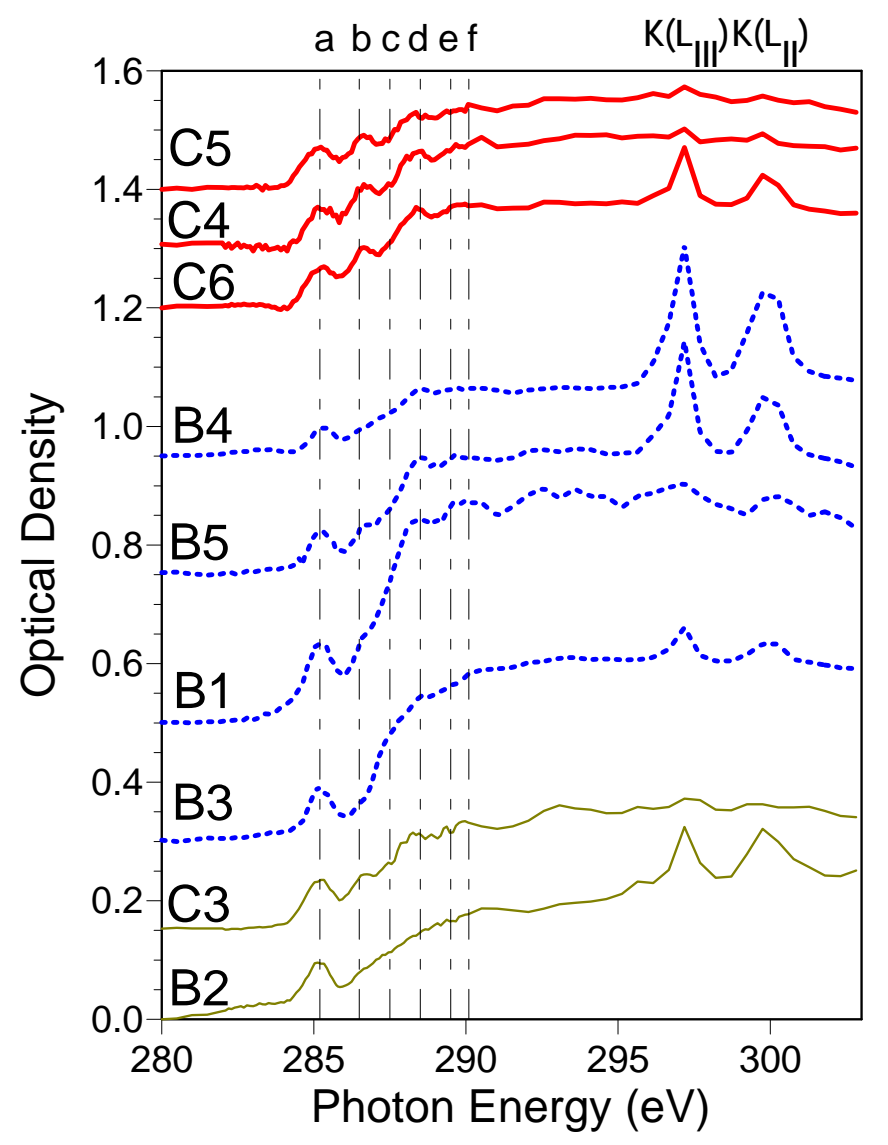

Figure 3 


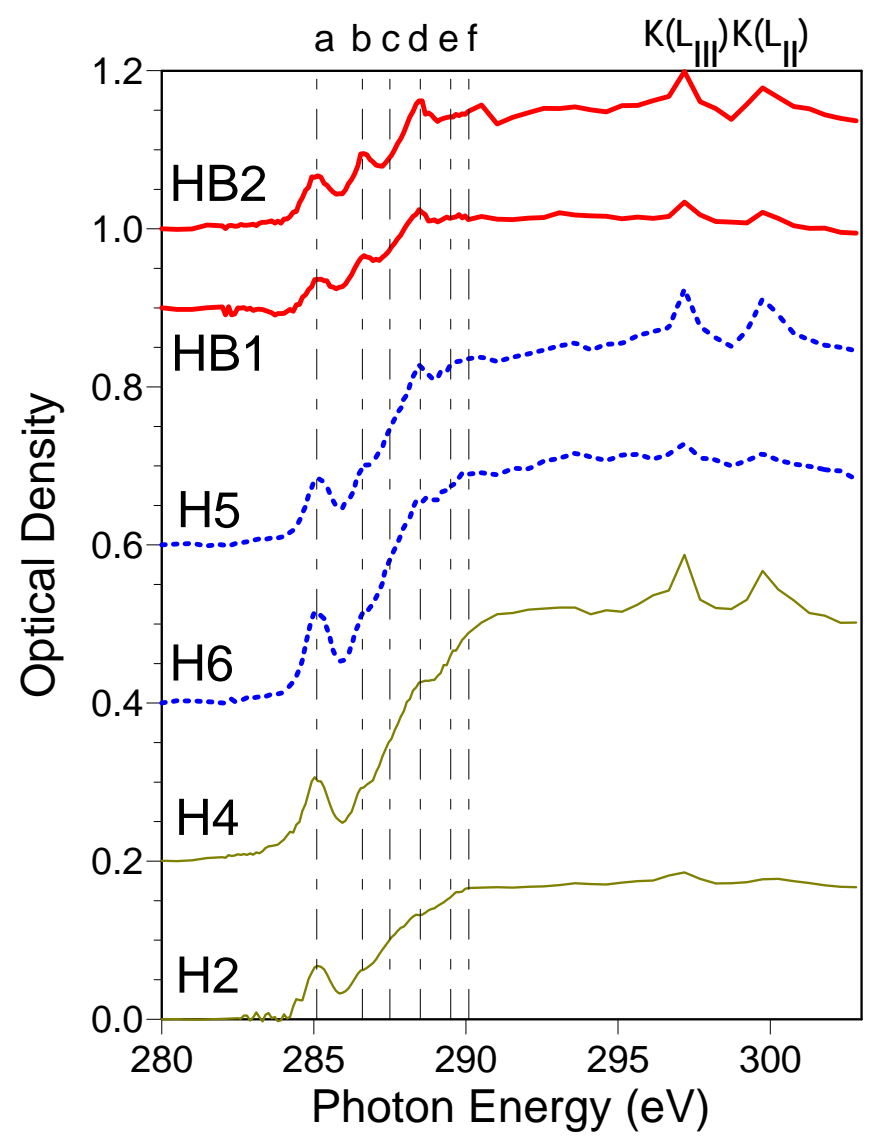

Figure 4 

Normalized spectra, combined

Type 1

$\mathbf{N}=\mathbf{1 0}$

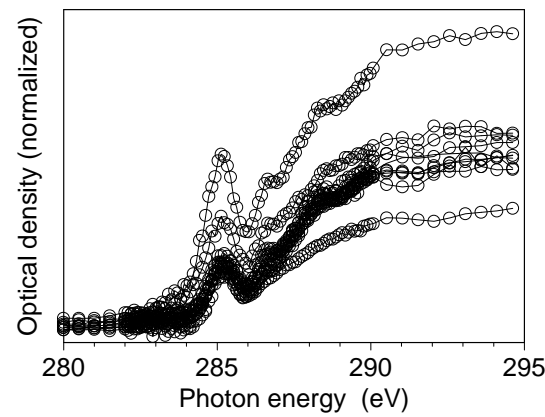

Type 2

$\mathbf{N}=7$

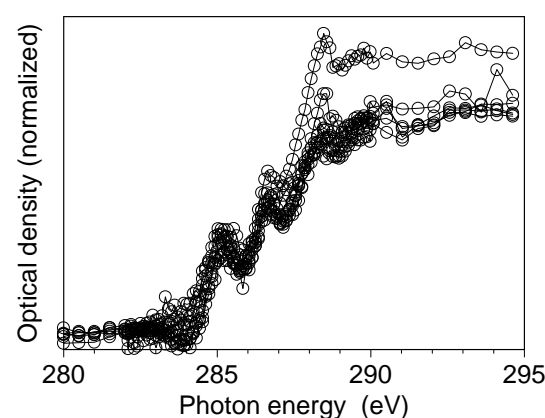

Type 3

$N=6$

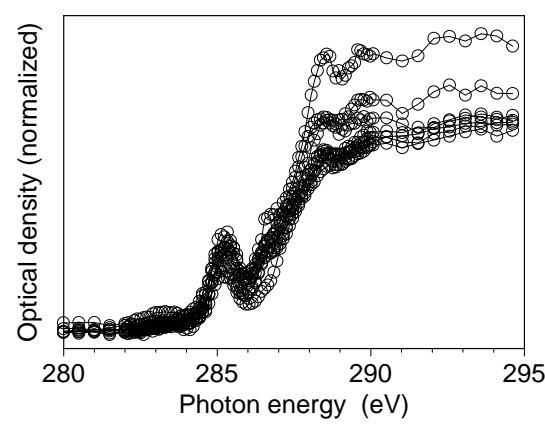

Average spectrum
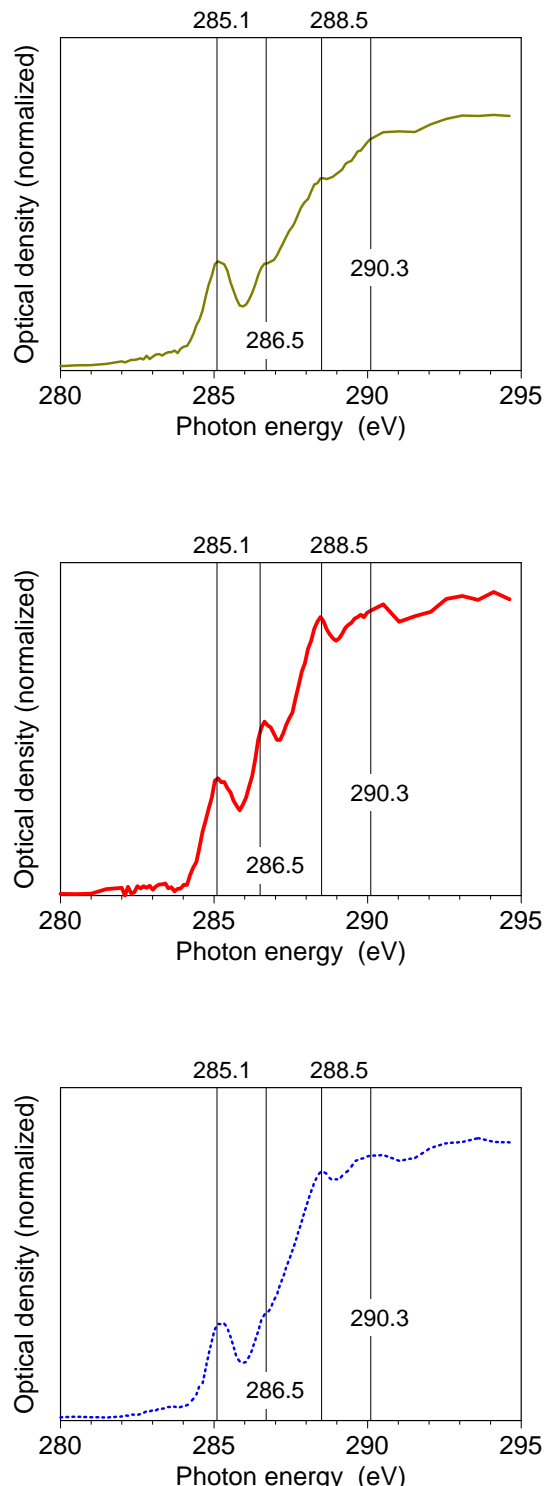

Figure 5

\section{Spectral type}
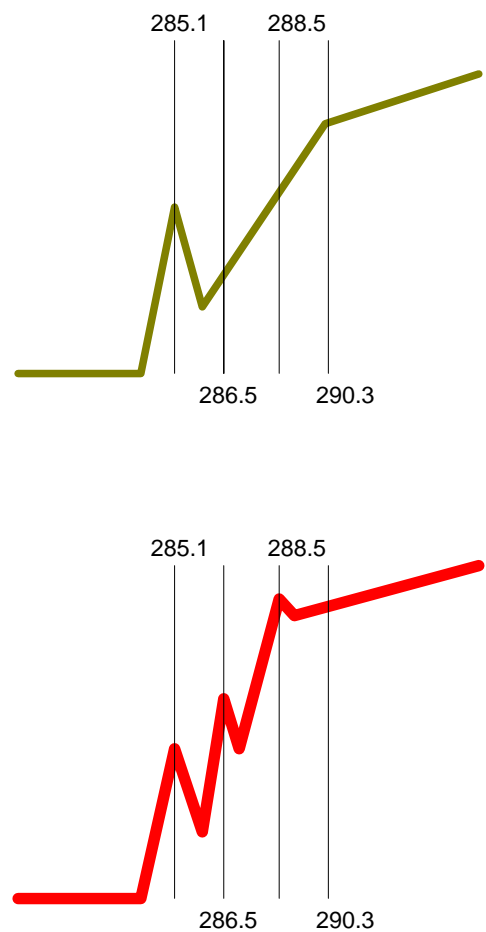

$286.5 \quad 290.3$

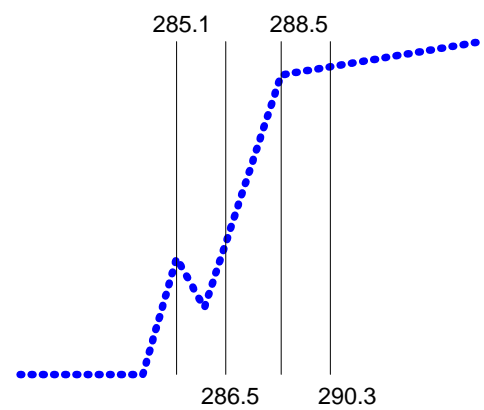



Acknowledgments. This work was supported by Oregon State University, Department of Crop and Soil Science and Subsurface Biosphere Initiative start-up funds to M. Kleber and by support from the U.S. Department of Energy, Office of Biological and Environmental Research, Climate and Environmental Science Division to P. Nico under Contract No. DEAC02-05CH11231. Access to beamlines 11.0.2 and 5.3.2 at the Advanced Light Source, Lawrence Berkeley National Laboratory, was provided by the Office of Science, Office of Basic Energy Science, Division of Materials Sciences, and Division of Chemical Sciences, Geosciences, Funding for the parent study came from USDA CSREES 2005-35107-16336 and NSF DEB-0515846 to P. Sollins and from USDA NRICGP 2002-35107-12249 to K. Lajtha. We would also like to thank the reviewers whose comments have helped to improve the manuscript.

\section{References}

Amelung W, Brodowski S, Sandhage-Hofmann A, Bol R (2008) Combining biomarker with stable isotope analyses for assessing the transformation and tuirnover of soil organic matter In: Advances in Agronomy Vol. 100. pp 155-250.

Baldock JA, Skjemstad JO (2000) Role of the soil matrix and minerals in protecting natural organic materials against biological attack. Organic Geochemistry, 31, 697-710.

Bol R, Poirier N, Balesdent J, Gleixner G (2009) Molecular turnover time of soil organic matter in particle-size fractions of an arable soil. Rapid Communications in Mass Spectrometry, 23, 2551-2558.

Bosatta E, Agren GI (1999) Soil organic matter quality interpreted thermodynamically. Soil Biology \& Biochemistry, 31, 1889-1891.

Brady NC, Weil RR (2008) The nature and properties of soils, Upper Saddle River, New Jersey, Prentice Hall.

Brandes JA, Lee C, Wakeham S, Peterson M, Jacobsen C, Wirick S, Cody G (2004) Examining marine particulate organic matter at sub-micron scales using scanning transmission X-ray microscopy and carbon X-ray absorption near edge structure spectroscopy. Marine Chemistry, 92, 107-121.

Burdon J (2001) Are the traditional concepts of the structures of humic substances realistic? Soil Science, 166, 752-769.

Buurman P, Peterse F, Martin GA (2007) Soil organic matter chemistry in allophanic soils: a pyrolysis-GC/MS study of a Costa Rican Andosol catena. European Journal of Soil Science, 58, 1330-1347.

Chen Y, Senesi N, Schnitzer M (1978) Chemical and physical characteristics of humic and fulvic acids extracted from soils of mediterranean region Geoderma, 20, 87-104. 
Cody GD, Ade H, Wirick S, Mitchell GD, Davis A (1998) Determination of chemicalstructural changes in vitrinite accompanying luminescence alteration using CNEXAFS analysis. Organic Geochemistry, 28, 441-455.

Conant RT, Drijber RA, Haddix ML et al. (2008) Sensitivity of organic matter decomposition to warming varies with its quality. Global Change Biology, 14, 868-877.

Czimczik CI, Masiello CA (2007) Controls on black carbon storage in soils. Global Biogeochemical Cycles, 21.

Davidson EA, Janssens IA (2006) Temperature sensitivity of soil carbon decomposition and feedbacks to climate change. Nature, 440, 165-173.

Falloon PD, Smith P (2000) Modelling refractory soil organic matter. Biology and Fertility of Soils, 30, 388-398.

Fang C, Smith P, Smith JU (2006) Is resistant soil organic matter more sensitive to temperature than the labile organic matter? Biogeosciences, 3, 65-68.

Feng XJ, Simpson MJ (2008) Temperature responses of individual soil organic matter components. Journal of Geophysical Research-Biogeosciences, 113, 14.

Filley TR, McCormick MK, Crow SE, Szlavecz K, Whigham DF, Johnston CT, van den Heuvel RN (2008) Comparison of the chemical alteration trajectory of Liriodendron tulipifera L. leaf litter among forests with different earthworm abundance. Journal of Geophysical Research-Biogeosciences, 113.

Flessa H, Amelung W, Helfrich M et al. (2008) Storage and stability of organic matter and fossil carbon in a Luvisol and Phaeozem with continuous maize cropping: A synthesis. Journal of Plant Nutrition and Soil Science-Zeitschrift Fur Pflanzenernahrung Und Bodenkunde, 171, 36-51.

Friedlingstein P, Cox P, Betts R et al. (2006) Climate-carbon cycle feedback analysis: Results from the (CMIP)-M-4 model intercomparison. Journal of Climate, 19, 3337-3353.

Goni MA, Hedges JI (1990) Cutin derived CUO reaction products from purified cuticles and tree leaves. Geochimica et Cosmochimica Acta, 54, 3065-3072.

Grandy AS, Neff JC (2008) Molecular C dynamics downstream: The biochemical decomposition sequence and its impact on soil organic matter structure and function. Science of The Total Environment, 404, 297-307.

Grasset L, Martinod J, Plante AF, Amblès A, Chenu C, Righi D (2009) Nature and origin of lipids in clay size fraction of a cultivated soil as revealed using preparative thermochemolysis. Organic Geochemistry, 40, 70-78.

Guggenberger G, Christensen BT, Zech W (1994) Land use effects on the composition of organic matter in particle size separates of soil: I. Lignin and carbohydrate signature. European Journal of Soil Science, 46, 449-458.

Hedges JI, Blanchette RA, Weliky K, Devol AH (1988) Effects of fungal degradation on the CUO Oxidation products of lignin - a controlled laboratory study. Geochimica et Cosmochimica Acta, 52, 2717-2726.

Hedges JI, Mann DC (1979) Characterization of plant tissues by their lignin oxidation products. Geochimica et Cosmochimica Acta, 43, 1803-1807.

Hedges JI, Oades JM (1997) Comparative organic geochemistries of soils and marine sediments. Organic Geochemistry, 27, 319-361.

Heimann M, Reichstein M (2008) Terrestrial ecosystem carbon dynamics and climate feedbacks. Nature, 451, 289-292.

Hitchcock AP (2006) aXis2000. Analysis of X-ray Images and Spectra. pp Page, McMaster University, Hamilton, Ontario, Canada.

Jenkinson DS, Poulton PR, Bryant C (2008) The turnover of organic carbon in subsoils. Part 1. Natural and bomb radiocarbon in soil profiles from the Rothamsted long-term field experiments. European Journal of Soil Science, 59, 391-U313. 
Kelleher BP, Simpson AJ (2006) Humic substances in soils: Are they really chemically distinct? Environmental Science \& Technology, 40, 4605-4611.

Kinyangi J, Solomon D, Liang BI, Lerotic M, Wirick S, Lehmann J (2006) Nanoscale biogeocomplexity of the organomineral assemblage in soil: Application of STXM microscopy and C 1s-NEXAFS spectroscopy. Soil Science Society of America Journal, 70, 1708-1718.

Kögel-Knabner I, Ekschmitt K, Flessa H, Guggenberger G, Matzner E, Marschner B, von Luetzow M (2008) An integrative approach of organic matter stabilization in temperate soils: Linking chemistry, physics, and biology. Journal of Plant Nutrition and Soil Science-Zeitschrift Fur Pflanzenernahrung Und Bodenkunde, 171, 5-13.

Kramer C, Gleixner G (2006) Variable use of plant- and soil-derived carbon by microorganisms in agricultural soils. Soil Biology \& Biochemistry, 38, 3267-3278.

Laird DA, Chappell MA, Martens DA, Wershaw RL, Thompson M (2008) Distinguishing black carbon from biogenic humic substances in soil clay fractions. Geoderma, 143, 115-122.

Lehmann J, Kinyangi J, Solomon D (2007) Organic matter stabilization in soil microaggregates: implications from spatial heterogeneity of organic carbon contents and carbon forms. Biogeochemistry, 85, 45-57.

Lehmann J, Liang B, Solomon D, Lerotic M, Luizao F, Schafer T, Wirick S (2005) Nearedge x-ray absorption fine structure (NEXAFS) spectroscopy for mapping nano-scale distribution of organic carbon forms in soils: Application to black carbon particles. Global Biogeochemical Cycles, 19, doi 10.1029/2004GB002435,002005.

Lehmann J, Solomon D, Kinyangi J, Dathe L, Wirick S, Jacobsen C (2008) Spatial complexity of soil organic matter forms at nanometre scales. Nature Geoscience, $\mathbf{1}$, $238-242$.

Leifeld J (2008) Calorimetric characterization of grass during its decomposition. Journal of Thermal Analysis and Calorimetry, 93, 651-655.

Lopez-Capel E, Sohi SP, Gaunt JL, Manning DAC (2005) Use of ThermogravimetryDifferential Scanning Calorimetry to Characterize Modelable Soil Organic Matter Fractions. Soil Sci Soc Am J, 69, 930-.

Marschner B, Brodowski S, Dreves A et al. (2008) How relevant is recalcitrance for the stabilization of organic matter in soils? Journal of Plant Nutrition and Soil ScienceZeitschrift Fur Pflanzenernahrung Und Bodenkunde, 171, 91-110.

Mayer LM, Xing B (2001) Organic matter - surface area relationships in acid soils. Soil Science Society of America Journal, 65, 250-258.

Metherell AK, Harding LA, Cole CV, Parton WJ (1993) CENTURY Soil organic matter model environment. Technical documentation, agroecosystem version 4.0. Great Plains System. Research Unit technical report no. 4., USDA-ARS, Fort Collins, Colo.

Paul EA, Morris SJ, Conant RT, Plante AF (2006) Does the Acid Hydrolysis-Incubation Method Measure Meaningful Soil Organic Carbon Pools? Soil Sci Soc Am J, 70, 1023-1035.

Piccolo A (2001) The supramolecular structure of humic substances. Soil Science, 166, 810832.

Plante AF, Pernes M, Chenu C (2005) Changes in clay-associated organic matter quality in a $\mathrm{C}$ depletion sequence as measured by differential thermal analyses. Geoderma, 129, 186-199.

Rasmussen C, Torn MS, Southard RJ (2005) Mineral assemblage and aggregates control carbon dynamics in a California conifer forest. Soil Science Society of America Journal, 69, 1711-1721. 
Schulten H-R, Schnitzer M (1997) Chemical model structures for soil organic matter and soils. Soil Science, 162, 115-130.

Schumacher M, Christl I, Scheinost AC, Jacobsen C, Kretzschmar R (2005) Chemical heterogeneity of organic soil colloids investigated by scanning transmission X-ray microscopy and C-1s NEXAFS microspectroscopy. Environmental Science and Technology, 39, 9094-9100.

Schumacher M, Christl I, Vogt RD, Barmettler K, Jacobsen C, Kretzschmar R (2006) Chemical composition of aquatic dissolved organic matter in five boreal forest catchments sampled in spring and fall seasons. Biogeochemistry, 80, 263-275.

Sollins P, Homann P, Caldwell BA (1996) Stabilization and destabilization of soil organic matter: Mechanisms and controls. Geoderma, 74, 65-105.

Sollins P, Kramer MG, Swanston C et al. (2009) Sequential density fractionation across soils of contrasting mineralogy: evidence for both microbial- and mineral-controlled soil organic matter stabilization. Biogeochemistry, 96, 209-231.

Sollins P, Swanston C, Kleber M et al. (2006) Organic C and N stabilization in a forest soil: Evidence from sequential density fractionation. Soil Biology and Biochemistry, 38, 3313-3324.

Solomon D, Lehmann J, Kinyangi J, Liang BQ, Schafer T (2005) Carbon K-edge NEXAFS and FTIR-ATR spectroscopic investigation of organic carbon speciation in soils. Soil Science Society of America Journal, 69, 107-119.

Sutton R, Sposito G (2005) Molecular structure in soil humic substances: The new view. Environmental Science \& Technology, 39, 9009-9015.

Swift R (1999) Macromolecular properties of soil humic substances: fact, fiction and opinion. Soil Science, 164, 790-802.

Torn MS, Swanston CW, Castanha C, Trumbore SE (2009) Storage and turnover of organic matter in soil. In: Biophysico-Chemical Processes Involving Natural Nonliving Organic Matter in Environmental Systems. (eds Senesi N., Xing B., Huang P. M.) pp 219-272. Hoboken, New Jersey, John Wiley \& Sons, Inc.

Trumbore S (2009) Radiocarbon and Soil Carbon Dynamics. Annual Review of Earth and Planetary Sciences, 37, 47-66.

Urquhart SG, Ade H (2002) Trends in the Carbonyl Core (C 1S, O 1S) $\pi * C=O$ Transition in the Near-Edge X-ray Absorption Fine Structure Spectra of Organic Molecules. $J$. Phys. Chem. B, 106, 8531-8538.

von Lützow M, Kögel-Knabner I (2009) Temperature sensitivity of soil organic matter decomposition-what do we know? Biology and Fertility of Soils, 46, 1-15.

Wan J, Tyliszczak T, Tokunaga TK (2007) Organic carbon distribution, speciation, and elemental correlations within soil microaggregates: Applications of STXM and NEXAFS spectroscopy. Geochimica et Cosmochimica Acta, 71, 5439-5449.

Wiesenberg GLB, Schwarzbauer J, Schmidt MWI, Schwark L (2004) Source and turnover of organic matter in agricultural soils derived from n-alkane/n-carboxylic acid compositions and C-isotope signatures. Organic Geochemistry, 35, 1371-1393.

Wixon DL, Balser TC (2009) Complexity, Climate Change and Soil Carbon: A Systems Approach to Microbial Temperature Response. Systems Research and Behavioral Science, 601-620. 